\title{
Antimicrobial Effects of Photodynamic Therapy Using Blue Light Emitting Diode with Photofrin and Radachlorine against Propionibacterium acnes
}

\author{
Pil-Seung Kwon \\ Department of Clinical Laboratory Science, Wonkwang Health Science University, Iksan 570-750, Korea
}

\begin{abstract}
Photodynamic therapy (PDT) apply photosensitizers and light. The purpose of this study was to evaluate the in vitro efficacy of PDT using blue LED (light emitting diode) with photofrin and radachlorin for Propionibacterium acnes. The colony forming units method was used to assess the antibacterial activity. Suspension ( $1 \mathrm{~mL}$ ) containing $P$. acnes at $1 \times 10^{5} \mathrm{CFU} / \mathrm{mL}$ were prepared and then 2 fold serial diluted to $12.5 \mu \mathrm{g} / \mathrm{mL}$ from $50 \mu \mathrm{g} / \mathrm{mL}$ concentration of photofrin and radachlorin. After 60 minutes incubation, light was irradiated for 10 to 30 minutes using the following light source of wavelength $460 \mathrm{~nm}$, each energy density 36,72 and $108 \mathrm{~J} / \mathrm{cm}^{2}$. Bacterial growth was evaluated after 72 hours incubation in a Phenylethanol Blood Agar (PEBA) culture. In addition, flow cytometric analysis were performed to measure the live cell after PDT. Also transmission electron microscopy (TEM) was employed to evaluate the effect of pathogens by PDT. The PDT Group was perfectly killed to all kind of photosensitizers dose of $12.5 \mu \mathrm{g} / \mathrm{mL}$ with irradiation of 10 minutes. Also other Groups were killed to all kind of photosensitizers dose of $6.25 \mu \mathrm{g} / \mathrm{mL}$ with irradiation time of 20 and 30 minutes. The flow cytometry showed a lower number of viable bacteria in the PDT group compared to the control group. The images of the TEM results were showed in cytoplasmic membrane damage and partially deformed to cell morphologies. These results suggest that radachlorin and photofrin combine blue LED PDT can be effectively treated when was proved

treatment for acnes therapy.
\end{abstract}

Keywords: Photodynamic therapy, Light Emitting Diode, Propionibacterium acnes, Photofrin, Radachlorine

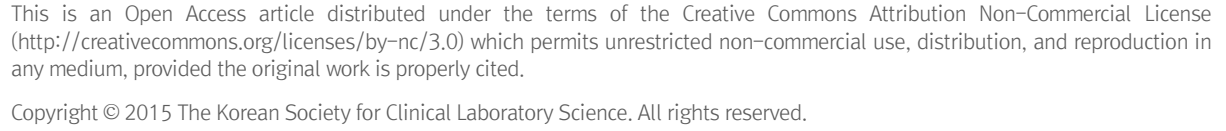

Copyright $@ 2015$ The Korean Society for Clinical Laboratory Science. All rights reserved.

Corresponding author: Pil-Seung Kwon Department of Clinical Laboratory Science, Wonkwang Health Science University, Iksan 570-750, Korea Tel: 82-63-840-1212 E-mail:pskwon@wu.ac.kr

Received: February 27, 2015

Revised: March 15, 2015

Accepted: March 16, 2015

\section{서 론}

여드름균은 그람양성 무산소성균이며, 정상적으로 피지선에서 발견되며, 염증으로의 진행에 중대한 영향을 미치는 인자이며, 홍 반의 발진과 농포와 소수의 경우 결절이나 낭포를 생기게 하는 특 성을 나타낼 수 있는 일반적인 피부질환이다(Akhavan과 Bershad, 2003; Haider와 Shaw, 2004). 후유증으로는 흉터가 남고 생활에 심리적인 위축이 되어 삶의 질을 떨어뜨리게 된다. 일반적으로 치 료는 항생제나 항염증제, 호르몬제, 레티노이드제를 바르거나 먹 는 것으로 치료를 하고 있으며, 이와 같은 치료는 성공적인 치료가 될 수도 있지만, 항생제 내성과 같은 부작용이 생길수도 있다 (Katsambas와 Dessinioti, 2008; Zaenglein 등, 2008). 특히, 국소
및 경구 항생제는 여드름의 주원인균인 Propionibacterium acnes 의 내성의 증가로 인해 문제가 되고 있다(Nord와 Oprica, 2006). 또한 여드름의 환자가 증가되는 문제들은 치료와 연관되어 일반적 인 인자로부터의 부작용이나 항균제 내성과 관련이 있다(Cooper, 1998; Eady 등, 2003).

광역학 치료(Photodynamic Therapy, PDT)는 항생제 내성에 서 자유로울 수 있는 치료방법의 대안으로 광역학 치료법이 대두되 고 있다. PDT는 레이저 빛에 예민한 반응을 보이는 광감작제 (Photosensitizer)를 종양에 투여하고 광감작제가 활성화되는 특 정 파장의 빛을 조사하여 광화학적 방법과 광생물학적 기전에 의해 암조직을 특이적으로 손상시키는 암치료 방법이다(Weishaupt $\mathrm{KR}$ 등, 1976). 광역학치료에 의한 세포내 작용기전의 시작은 광 - 
물리현상으로 이해되고 있는데 기저상태의 광감작제를 특정파장 의 빛으로 활성화시켜 단일항 상태나 삼중항 상태로 되고 여기서 기저상태로 될 때 방출되는 에너지가 산소와 반응하여 활성산소 $\left(\mathrm{O}_{2}\right)$ 를 생성시키거나(TypeII 반응) 감작제가 전자전달계에 관여하 는 경우 자유라디칼이 형성되어(TypeI 반응) 세포파괴가 일어난다 (Ochsner, 1997). 407 420 nm 영역의 청색광은 다른색 광원과 비교하여 조사하였을 때 여드름 균에 효과적인 살균효과를 가져온 다고 알려져 있다(Elman과 Lebzelter, 2004; Mariwalla와 Rohrer, 2005). 그리고 광감작제는 5-aminolevulinic acid (ALA)을 이용 한 광역학 치료에 대한 선행연구들이 이루어져 있지만, 포피린 계 열의 포토프린과 클로린 계열의 라다클로린에 대한 연구된 바가 없 어 저자들은 여드름의 원인균을 대상으로 청색광의 발광다이오드 (Light Emitting Diode, LED)를 이용한 광역학 치료법을 시행하여 두 종류의 광감작제별 효과와 청색광 LED가 미치는 효과를 비교하 고자 하였다.

\section{재료 및 방법}

\section{1. 대상균주}

표준균주 Propionibacterium acnes (ATCC 6919)을 50\% glycerol-brain heart infusion broth에 접종하여 $-70^{\circ} \mathrm{C}$ 냉동고에 보관하였고, 균주를 Phenylethanol Blood Agar (PEBA)를 직접 제조 하여 가스발생봉지를 무산소성 단지에 넣고 $37^{\circ} \mathrm{C}$ 배양기(Thermo Forma, 47502-3362)에서 72시간동안 배양하여 사용하였다.

\section{2. 광원과 광감작제}

본 연구에 사용된 광감작제 photofrin (Axcan Pharma Inc, canada)은 Dulbecco's phosphate buffered saline (Hyclone, $\mathrm{USA}$ )에 $1,000 \mathrm{mg} / \mathrm{mL}$ 로 녹여 만든 뒤 $0.2 \mu \mathrm{m}$ filter로 여과하여 사 용하였고, radachlorin (RADA-PHARMA Co, Ltd., Moscow, Russia)은 액체앰플을 Dulbecco's phosphate buffered saline (Hyclone, USA)에 1,000 $\mu \mathrm{g} / \mathrm{mL}$ 로 희석하여 사용하였다.

광원은 $\mathrm{LED}$ 를 자체 제작하여 사용하였고, 사용된 $\mathrm{LED}$ 는 $5 \Phi$ 의 원통모양으로 시험관에 조사하기 위해 $460 \mathrm{~nm} \mathrm{LED} \mathrm{array를} \mathrm{제작}$ 하였다. LED의 회로 연결은 직렬과 병렬을 병합하여 사용하였고, 직류 전원을 사용하였다. LED array와 조사받는 플레이트와의 10 $\mathrm{mm}$ 거리를 두었고, 에너지 밀도 $60 \mathrm{~mW} / \mathrm{cm}^{2}$ 로 $10,20,30$ 분 동안 조사하였다. 이때 최종 에너지는 각각 $36,72,108 \mathrm{~J} / \mathrm{cm}^{2}$ 이였다.

\section{CFU (Colony Forming Units)측정}

멸균된 시험관을 사용하여 배양된 집락을 멸균된 면봉으로 묻혀
Muller hintone broth에 혼합하여 탁도계(Densicheck plus, biomeriex, USA)를 이용하여 McFarland No. 0.5로 맞춘 후 $1.5 \times 10^{5}$ cells $/ \mathrm{mL}$ 가 되도록 $12 \times 75 \mathrm{~mm}$ Polyethylene cap tube (SPL Life Sciences, Korea)에 계단 희석하여 균주부유액을 만들었 다. 광감작제인 photofrin과 radachlorin은 균주부유액과 함께 계 단희석하여 최종농도 $50,25,12.5,6.25 \mu \mathrm{g} / \mathrm{mL}$ 가 되도록 한 후 24 well plate에 혼합하였다. 그 후 알루미늄 호일을 이용하여 빛을 차 단시키고 $37^{\circ} \mathrm{C}$ 배양기(Thermo Forma, $47502-3362$ )에서 1 시간 동안 배양하였다. 그 후 $460 \mathrm{~nm}$ 의 LED 광원을 $10,20,30$ 분 동안 빛을 조사하였다. LED 조사가 끝난 후 혼합기로 혼합 후 Phenylethanol Blood Agar (PEBA)에 각 군별로 $50 \mu \mathrm{L}$ 씩 분주 후 스프레더를 이용하여 접종한 후 72 시간 배양시킨 후 생성된 집락 의 수를 세었다. 각 그룹별로 대조군은 Control, L+P-은 LED 빛만 조사한 군, L-P+은 포토프린과 라다클로린 $10 \mu \mathrm{g} / \mathrm{mL}$ 만 처리한 군, $\mathrm{L}+\mathrm{P}+50$ 은 포토프린과 라다클로린 $50 \mu \mathrm{g} / \mathrm{mL}$ 와 LED를 조사한 PDT군이며, 또한 $\mathrm{L}+\mathrm{P}+25, \mathrm{~L}+\mathrm{P}+12.5, \mathrm{~L}+\mathrm{P}+6.25$ 는 포토프린과 라다클로린을 2 배씩 계단희석하여 LED를 조사한 PDT군이다. 각 그룹 당 6회 측정하였으며, 100 개 이상 되는 집락에 대해서는 멸균 된 Normal Saline으로 희석하여 집락수를 세었다.

\section{4. 유세포분석}

유세포분석을 위하여 $\mathrm{CFU}$ 측정과 같은 방법으로 광감작제인 photofrin과 radachlorin을 균주부유액과 함께 계단희석하여 각 각 고농도 $50 \mu \mathrm{g} / \mathrm{mL}$ 가 되도록 한 후 1시간 배양하고 $460 \mathrm{~nm}$ 의 $\mathrm{LED}$ 광원을 30 분간 빛 조사하여 광역학치료를 하였다. 이때 최종 에너지밀도는 $108 \mathrm{~J} / \mathrm{cm}^{2}$ 였다. 치료 후의 균주 부유액을 다시 한 번 stain buffer $1 \mathrm{~mL}$ 씩 첨가한 후 가볍게 혼합 후 $1300 \mathrm{rpm}$ 으로 5 분 간 원심분리 하였다. 상층액을 버린 후 침사층에 stain buffer 0.5 $\mathrm{mL}$ 씩 각 균주에 분주한 후 염색시약 Thiazole orange $(\mathrm{BD}$, catalog No. 349483)를 $5 \mu \mathrm{L}$ 씩 분주하고 vortex mixer 한 후 5 분 동안 실온에서 항온 시켜서 염색시켰다. 그 후 flow cytometry (BD, FACSCAN)으로 30,000 개의 세포를 세어 분석하였다. 이때 사용된 레이저 파장은 $488 \mathrm{~nm}$ 의 laser excitation이였으며 분석기 의 초기 instrument setting은 threshold-SSC, FSC-E01, SSC-375V, FL1-600V, FL3-800V이였다. 분석프로그램은 BD사 CellQuest-pro를 사용하였다.

\section{5. 투과전자현미경적 관찰}

$\mathrm{PDT}$ 후 CFU test를 해본 결과를 얻은 후 살균효과를 보인 광감 작제 농도의 tube에서 균주희석액과 대조군의 균주희석액을 tube 에 취하여 동량의 $5 \%$ glutaraldehyde (PH7.4)로 $4^{\circ} \mathrm{C}$ 에서 12 시간 
8 Pil-Seung Kwon. Antimicrobial Effects of Photodynamic Therapy Using Blue Light Emitting Diode

전 고정하였다. 5,000 g에 20분간 원심분리하고 상층액은 버린 후 얻어진 pellets를 $2 \%$ osmium tetroxide용액 $1 \mathrm{~mL}$ 을 첨가하고 1 시간 후 고정을 실시하였다.

그 후 DPBS용액으로 washing을 2회 실시하고 그 후 에탄올로 탈수시키고 Eponate로 포매했다. $60^{\circ} \mathrm{C}$ 오븐에서 40시간 경화시 켰다. Block을 ultra micro tome으로 준초박절편을 $0.4 \mu \mathrm{m}$ 로 만 들고 이를 toluidine blue로 염색 후 광학현미경으로 정확한 부위 를 확인한 다음 초박절편 $50 \mathrm{~nm}$ 로 얇게 만들었다. Uranyl acetate 와 lead acetate로 이중염색을 하였다. 투과전자현미경(HITACHI, $\mathrm{H}-7000 \mathrm{~B}$ 모델) $75 \mathrm{KV}$ 으로 세균의 형태를 관찰하였다.

\section{결 과}

\section{CFU측정 결과}

10 분간 조사한 PDT 결과는 photofrin과 radachlorin 모두에서
$\mathrm{L}+\mathrm{P}+6.25$ 에서 각각 평균 40,60 개의 집락형성이 되었으며, $\mathrm{L}+\mathrm{P}+12.5$ 와 $\mathrm{L}+\mathrm{P}+50$ 의 고농도에서는 모두 완전히 사멸되어 집락 형성이 없었다. 20분과 30분간 조사한 PDT 결과는 photofrin과 radachlorin 모두에서 $6.25 \mathrm{~L}+\mathrm{P}+12.5$ 와 $\mathrm{L}+\mathrm{P}+50$ 의 고농도까지 모두 완전히 사멸되어 집락형성이 없었다(Table 1).

\section{2. 유세포분석 결과}

유세포 분석 결과는 X축은 Thiazole orange에 염색 된 세균의 염색강도는 핵산에 침투하여 살아있는 세포만 염색이 된다. Y축은 세균의 개체수를 나타낸다.

먼저 X축 FSC (Forward Scotter)와 Y축 SSC (Side scotter)를 지정하고 대조군을 분석하여 집락을 형성하는 부위를 확인하였다. 그 다음 histogram을 그려서 분석하였다. 분석한 그래프에서 Marker를 표시하여 정량적으로 분석하였다. M1은 염색의 강도가 약한 영역을 M1으로 표시하였고, M2는 염색강도가 강하고 정상적

Table 1. Comparisons of colony forming units by time series on photofrin and radachlorin PDT

\begin{tabular}{|c|c|c|c|c|c|c|}
\hline \multirow{2}{*}{ PDT classification } & \multicolumn{2}{|c|}{$10 \mathrm{~min}$} & \multicolumn{2}{|c|}{$20 \mathrm{~min}$} & \multicolumn{2}{|c|}{$30 \mathrm{~min}$} \\
\hline & PF & Rada & PF & Rada & PF & Rada \\
\hline Control & 20000 & 14120 & 26420 & 24380 & 23540 & 19900 \\
\hline$L+P-$ & 15520 & 13080 & 23840 & 18960 & 12840 & 11500 \\
\hline L-P+ & 12820 & 2080 & 24940 & 23320 & 9000 & 12420 \\
\hline$L+P 50$ & 0 & 0 & 0 & 0 & 0 & 0 \\
\hline$L+P 25$ & 0 & 0 & 0 & 0 & 0 & 0 \\
\hline$L+P 12.5$ & 0 & 0 & 0 & 0 & 0 & 0 \\
\hline$L+P 6.25$ & 40 & 60 & 0 & 0 & 0 & 0 \\
\hline
\end{tabular}

PF, photofrin; Rada, radachlorin.
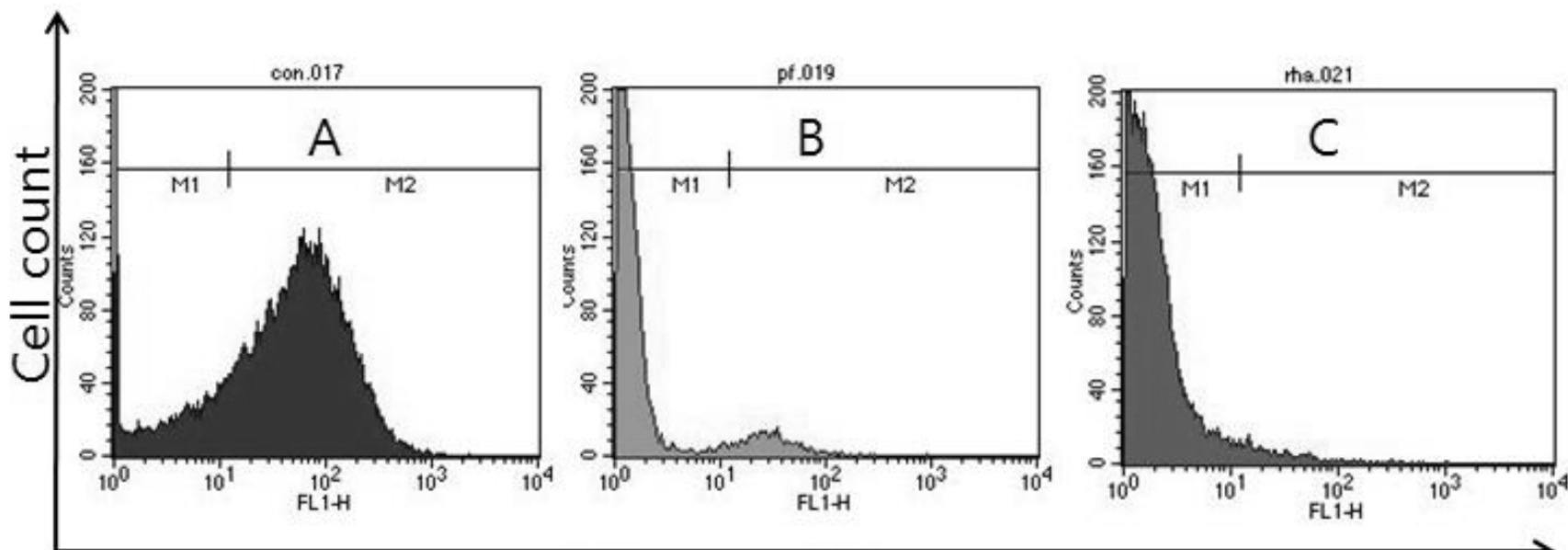

\section{Fluorescent intensity}

Fig. 1. The histograms of $P$. acnes suspensions on flow cytometry after PDT by stained with thiazole orange. The results were counted to each 30,000 cells for $P$. acnes. The PDT was performed $460 \mathrm{~nm} \mathrm{LED}\left(108 \mathrm{~J} / \mathrm{cm}^{2}\right)$ with photofrin and radachlorin $(50 \mu \mathrm{g} / \mathrm{mL}) \mathrm{on}$ bacterial suspensions. The M1 section of the histogram showed the number of weakly viable cells and the $\mathrm{M} 2$ section represents the number of live cells. (A) Control group. (B) PDT with photofrin. (C) PDT with radachlorin. 


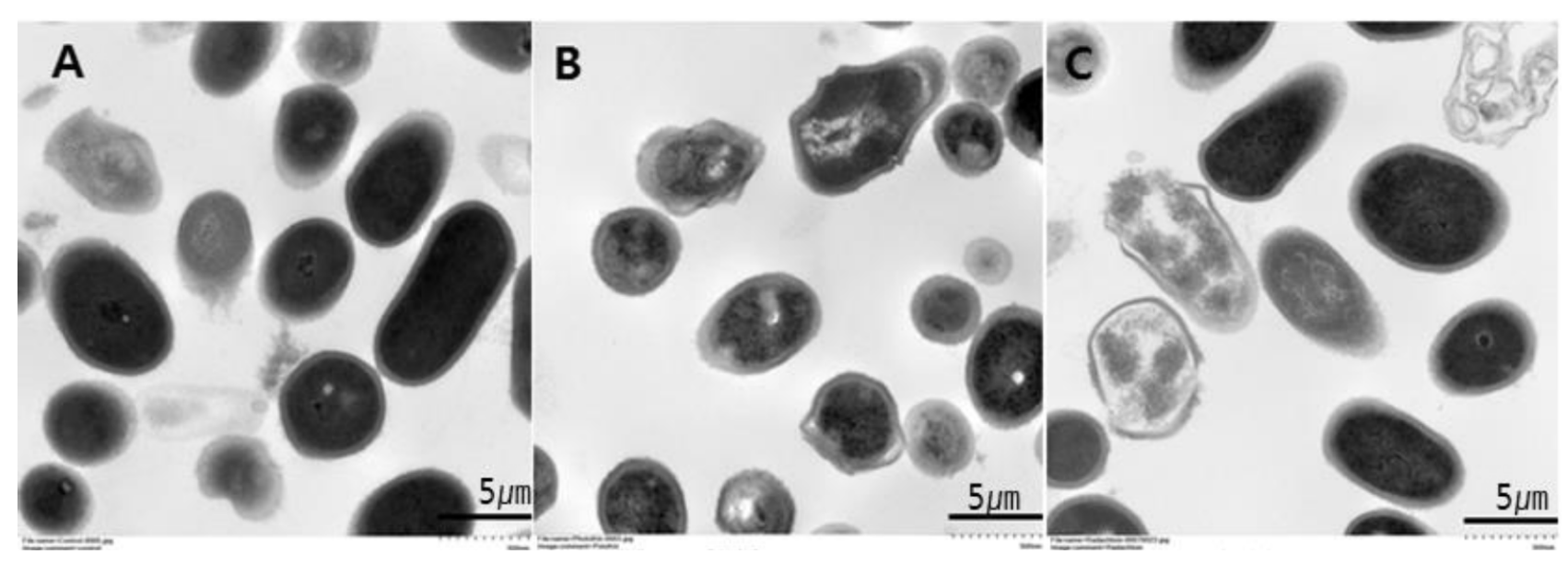

Fig. 2. Transmission electron microscopic findings after photodynamic therapy (PDT). In the PDT group of $P$. acnes with photofrin and radachlorin, partially cell morphologies were distorted, part of the cell membrane was disrupted with a leaking intracellular substance. (A) Control group $(\times 10,000)$. (B) PDT with photofrin $(\times 10,000)$. (C) PDT with radachlorin $(\times 10,000)$. Scale bar: $5 \mu \mathrm{m}$.

으로 살아있는 영역을 선택하였다.

P. acnes는 정상 대조군(Control) 분석결과는 Events수를 30,000 개 일 때 M1이 21\%를 차지하고 M2는 79\%를 차지했으며 이와 대조적으로, photofrin L+P+50의 고농도에서 PDT군의 분석 결과는 Events수를 30,000개 일 때 M1이 97\%를 차지하고 M2는 $3 \%$ 를 차지했고, radachlorin L+P+50의 고농도에서 PDT군의 분 석결과는 Events수를 30,000개 일 때 M1이 98\%를 차지하고 M2 는 $2 \%$ 를 차지했다(Fig. 1). 이 결과로 광역학 치료 후의 세균의 살아 있는 세포수의 감소된 것을 확인하였다.

\section{3. 투과전자현미경적 형태분석}

P. acnes의 대조군에는 세포벽과 세포질막이 선명한 모습으로 관찰되며 세포질내의 구조물도 특별한 변화 없이 나타났다. 그러나 포토프린과 라다클로린 PDT후의 P. acnes의 형태관찰은 세포막 형태의 손상과 세포질내 손상이 관찰되었다. 그리고 작은 크기의 액포들이 세포질내에서 관찰할 수 있었다. 이런 액포들은 구조적인 이상을 보인 세균들의 상당수에서 관찰할 수 있었다(Fig. 2).

\section{고 찰}

P. acnes는 정상적 대사과정이나 증식단계의 일부분에서 protoporphyrin (Pp IX), uroporphyrin, coproporphyrin III라 는 이름의 내인성 porphyrin의 축적이 일어난다(Ashkenazi 등, 2003). 이 porphyrin은 근자외선과 파란색광에서 흡수가 일어나 게 된다.

광감작제인 5-aminolevulinic acid (ALA)가 Pp IX축척을 증진 시키케 하는 대표적인 광감작제로 적용되고 있다(Divaris 등, 1990; Zeina 등, 2001; Ashkenazi 등, 2003; Borelli 등, 2006). 그
러나ALA를 사용한 광역학 치료법은 통증, 홍반, 농포성 발진, 수포 등 부작용과 대사시간이 길다는 단점이 있어서 사용에 제한적이다. $\mathrm{Pp} \mathrm{IX}$ 은 광에 감작되어 대사되어지고 여드름 피부 안에서 많은 양 을 생산하는 광감작제이다. Pp IX형태는 적합한 파장의 빛을 받으 면 세포독성인자인 일중항산소와 자유라디컬에 의해 광활성이 일 어나세포의 핵과 세포막의 파괴와자기사멸사를 일으키고, P. acnes 의 세포벽안의 지질들을 파괴한다(Elman과 Lebzelter, 2004).

2013년, Reena과 Karthika에 의하면 광역학치료는 3가지의 인 자인 광감작제, 광원과 산소가 필요하며 여드름치료에 사용되어진 광감작제는 ALA가 대부분이며, 새로운 광감작제로 indocyanine green (ICG)와 Indole-3-acetic acid를 제시하였다.

최근 2011년, 국내의 장 등에 의한 연구결과를 보면 여드름환자 34 명의 환자를 대상으로 $520 \mathrm{~nm}$ 녹색광원에 ICG와 $805 \mathrm{~nm}$ 광원 에 Indole-3-acetic acid를 사용하여 모두 염증소견을 보이는 환 자가 비염증성 환자보다 부작용 없이 좋은 효과를 보인 것을 보고 하였다. 그리고 2007년, 국내 연구자 홍 등은 본 연구에 사용된 Porphyrin 계열인 photogem을 이용한 Moraxella 균을 100\% 사멸 을 증명하였고, 2011년, 권은 Vancomycin-resistant Enterococci 에 대한 $100 \%$ 사멸을 증명하였다. 그러나 본 연구에서는 아직까지 사용이 드문 광감작제인 Porphyrin 계열인 photofrin과 클로린 계 열인 radachlorine으로 연구하였으며, 클로린 계열은 최근에 주목 받고 있는 광감작제이며, 부작용이 적고 대사시간이 짧은 것이 장 점으로 알려져 있다. 대부분의 임상연구에 의하면, 여드름의 광역 학적 치료가 P. acnes의 사멸 뿐 만 아니라 모낭피지샘의 손상도 있 는 것으로 보고 되고 있다(Peng 등, 1992; Hongcharu 등, 2000; Bhardwaj 등, 2005). 그러나 본 연구는 체외적 실험의 결과로 $P$. acnes의 집락형성수가 $100 \%$ 사멸됨을 관찰하였다.

2005년 Morton 등은 409 419 nm 청색 LED 광원을 40 
$\mathrm{mW} / \mathrm{cm}^{2}$ 의 에너지 출력을 사용하여 30 명의 환자를 대상으로 얼 굴에 적용하여 염증소견의 감소를 증명하였다. 본 연구에 사용된 파장은 $460 \mathrm{~nm}$ 청색 $\mathrm{LED}$ 를 사용하였으며 에너지는 $36 \mathrm{~J} / \mathrm{cm}^{2}$ 에서 광감작제의 농도를 $12.5 \mu \mathrm{g} / \mathrm{mL}$ 이상을 사용하면 효과적 집락형성 수가 보인 것을 감안하면, photofrin과 radachlorine 모두 임상적 효과를 기대해 볼 수 있는 연구결과임에 틀림없다(Table 1). 2006 년 Horfelt 등과 Wiegell과 Wulf의 연구 결과에는 적색광인 635 $\mathrm{nm}$ 파장의 빛을 이용하고 ALA-PDT의 효과를 증명한 좋은 예이 고, 본 연구에서는 적색파장의 결과가 없어서 향후 연구해야할 것 으로 사료된다. 2008년, Girish 등에 의한 여드름치료의 레이저와 광기반에 의한 근거 중심의 문헌에서는 PDT가 가장 많이 연구한 부분으로 신뢰도가 높은 치료법으로 평가되었다.

본 실험에서는 체외적으로 그동안 시도가 없던 photofrin과 radachlorine의 광감작제로 청색광 $460 \mathrm{~nm} \mathrm{LED}$ 를 이용한 PDT가 집락형성수시험에서 우수하게 살균효과를 증명하였으로 전자현 미경적 세균형태 변화는 메커니즘의 규명에 도움을 주었다.

결론적으로, 자체제작한 $460 \mathrm{~nm} \mathrm{LED}$ 청색광으로 $36 \mathrm{~J} / \mathrm{cm}^{2}$ 에너 지 조사와 photofrin과 rada chlorine 광감작제를 이용한 광역학 치료가 P. acnes에 효과적으로 살균될 수 있음을 증명하였다.

Acknowledgements: 이 논문은 2014년도 원광보건대학교 교내 연구비 지원에 의해서 수행됨.

Funding: None

Conflict of interest: None

\section{References}

1. Akhavan A, Bershad S. Topical acne drugs: review of clinical properties, systemic exposure, and safety. Am J Clin Dermatol. 2003, 4(7):473-492.

2. Ashkenazi H, Malik Z, Harth Y, Nitzan Y. Eradication of Propionibacterium acnes by its endogenic porphyrins after illumination with high intensity blue light. FEMS Immunol Med Microbiol. 2003, 35:17-24.

3. Bhardwaj S, Rohrer TE, Arndt K. Lasers and light therapy for acne vulgaris. Semin Cutan Med Surg. 2005, 24:107-112.

4. Borelli C, Merk K, Schaller M, Jacob K, Vogeser M, Weindl G, et al. In vivo porphyrin production by $\mathrm{P}$. acnes in untreated acne patients and its modulation by acne treatment. Acta Derm Venereol. 2006, 86:316-319.

5. Cooper AJ. Systematic review of Propionibacterium acnes resistance to systemic antibiotics. Med J Aust. 1998, 169(5):259-261.

6. Divaris DX, Kennedy JC, Pottier RH. Phototoxic damage to se- baceous glands and hair follicles of mice after systemic administration of 5-aminolevulinic acid correlates with localized protoporphyrin IX fluorescence. Am J Pathol. 1990, 136:891-897.

7. Eady AE, Cove JH, Layton AM. Is antibiotic resistance in cutaneous propionibacteria clinically relevant?: implications of resistance for acne patients andprescribers. Am J Clin Dermatol. 2003, 4(12):813-831

8. Elman M, Lebzelter J. Light therapy in the treatment of acne vulgaris. Dermatol Surg. 2004, 30:139-146.

9. Haider A, Shaw JC. Treatment of acne vulgaris. JAMA. 2004, 292(6):726-735.

10. Hongcharu W, Taylor CR, Chang Y, Aghassi D, Suthamjariya K, Anderson RR. Topical ALA-photodynamic therapy for the treatment of acne vulgaris. J Invest Dermatol. 2000, 115:183-92.

11. Hong SN, Kwon PS, Kim DS. Photodynamic Inactivation of Moraxella catarrhalis. Korean J Clin Lab Sci. 2007, 39:19-24.

12. Horfelt C, Funk J, Frohm-Nilsson M, Wiegleb Edstrom D, Wennberg AM. Topical methyl aminolevulinate photodynamic therapy for treatment of facial acne vulgaris, Results of a randomized, controlled study. BrJ Dermatol. 2006, 155:608-613.

13. Jang MS, Doh KS, Kang JS, Jeon YS, Suh KS, Kim ST. A comparative split face study of photodynamic therapy with indocyanine green and indole- 3-acetic acid for the treatment of acne vulgaris. BrJ Dermatol. 2011, 165:1095-1100.

14. Katsambas A, Dessinioti C. New and emerging treatments in dermatology: acne. Dermatol Ther. 2008, 21:86-95

15. Kwon PS. The Effects of Photodynamic Therapy for Vancomycinresistant Enterococci. Korean J Clin Lab Sci. 2011, 43:124-132.

16. Mariwalla K, Rohrer TE. Use of lasers and light-based therapies for treatment of acne vulgaris. Lasers Surg Med. 2005, 37(5): 333-342.

17. Morton CA, Scholefield RD, Whitehurst C, Birch J. An open study to determine the efficacy of blue light in the treatment of mild to moderate acne. J Dermatol Treat. 2005, 16:219-223.

18. Ochsner M. New trends in photo biology of photophysical and photobiological processes in the photodynamic therapy of tumors. Photochem Photobiol. 1997, 39:1-18.

19. Peng Q, Moan J, Warloe T, Nesland JM, Rimington C. Distribution and photosensitizing efficiency of porphyrins induced by application of exogenous 5-amino -levulinic acid in mice bearing mammary carcinoma. Int J Cancer. 1992, 52:433-43.

20. Rai R, Natarajan K. Laser and light based treatments of acne. Indian J Dermatol Venereol Leprol. 2013, 79(3):300-9.

21. Weishaupt KR, Gomer CJ, Dougherty TJ. Identification of singlet oxygen as the cytotoxic agent in photoinactivation of a murine tumor. Cancer Res. 1976, 36:2326-2329.

22. Wiegell SR, Wulf HC. Photodynamic therapy of acne vulgaris using 5-aminolevulinic acid versus methyl aminolevulinate. $J$ Am Acad Dermatol. 2006, 54:647-651.

23. Zaenglein AL, Graber EM, Thiboutot DM, Straiss JS. Acne vulgaris and acnei form eruptions. In: Wolff K, Goldsmith LA, Katz SI, Gilchrest BA, Paller AS, Leffell DJ. Fitzpatrick's dermatology in general medicine. 7th eds, 2008, p690-700. McGraw-Hill, New York. 